\title{
BIONATURE
}

p-ISSN 1411 - 4720

e-ISSN 2654 - 5160

Abstract. This research is a descriptive study that aims to determine the morphological characteristics of Marica goats. That are kept outside the habitat. Observation of morphological characteristics and eating activities using 2 goats (1 male and 1 female). This research was conducted at the Biology Experiment Garden in Makassar State University. The results obtained by Marica Goat have a relatively small body dimensions, upright ears and relatively small short, short and small horns and look agile and aggressive and Marica goats during the day (09.00-16.00) do more eating activities.

Keywords: Marica Goat, morphological characteristicsm and eating activities.

Rosdiana Ngitung
Universitas Negeri Makassar Indonesia

Mushawwir Tayyeb Universitas Negeri Makassar Indonesia

Irma Suryani Idris Universitas Negeri Makassar Indonesia

\section{Identifikasi Morfologi dan Perilaku Makan Kambing Marica yang Dipelihara di Luar Habitat}

\author{
Rosdiana Ngitung \\ Mushawwir Tayyeb \\ Irma Suryani Idris
}

Abstrak. Penelitian ini adalah penelitian deskriftif yang bertujuan untuk mengetahui karakteristik morfologi kambing Marica yang Dipelihara di luar Habitatnya. Pada pengamatan karakteristik morfologi dan perilaku makan menggunakan 2 ekor kambing (1 ekor jantan dan 1 ekor betina). Penilitian ini dilaksanakan di Kebun Percobaan Biologi Universitas Negeri Makassar. Hasil penelitian diperoleh Kambing Marica memiliki ukuran dimensi tubuh yang relatif kecil, telinganya tegak dan relatif kecil pendek, tanduk pendek dan kecil serta kelihatan lincah dan agresif serta kambing Marica pada siang hari (09.00-16.00) lebih banyak melakukan aktivitas makan.

Kata Kunci: Kambing Marica, krakteristik morfologi, dan perilaku makan.

\section{Pendahuluan}

Kambing merupakan hewan pertama yang didomestikasi. MacHugh, dkk (2001) mengemukakan kambing diduga berasal dari Kambing liar Capra aegargus. Pada awalnya sekitar 10 000-11 000 tahun yang silam di daerah Kawasan Timur Tengah manusia zaman Neolithic mulai memelihara kambing dalam jumlah kecil untuk mendapatkan susu, daging dan kotorannya sebagai bahan bakar, juga sebagai bahan untuk pakaian dan bangunan yang terbuat dari bulu, tulang, kulit dan urat daging. Kambing merupakan ternak yang cukup dikenal di Indonesia. Riswandi dan Muslima (2018) mengemukakan kambing merupakan salah satu ternak ruminansia yang telah dikenal luas di Indonesia. Ternak kambing di Indonesia memiliki produktivitas cukup tinggi sebagai penghasil susu dan kulitnya yang memiliki nilai ekonomis. Jumlah kambing di Sulawesi Selatan meningkat setiap tahunnya. Menurut Dinas Peternakan dan Kesehatan Hewan Provinsi Sulawesi Selatan jumlah kambing mengalami peningkatan dari tahun 2015 yang berjumlah 691.022 ekor ke tahun 2017 yang berjumlah 797.284 ekor, akan tetapi terdapat beberapa jenis kambing yang hampir punah salah satunya adalah kambing Marica. Kambing Marica merupakan salah satu plasma nutfah endemik Sulawesi Selatan yang kelestariannya sedang terancam punah. Untuk itu perlu suatu upaya untuk dapat menjamin kelestarian jenis kambing tersebut. Salah satu upaya yang dapat dilakukan adalah pengembangan kambing Marica secara ex-situ melalui perbaikan manajemen pemeliharaan dan pemberian pakan. Namun terdapat masalah yang 
dihadapi oleh karena informasi-informasi dasar terutama yang terkait dengan aspek biologis dan ekologis dari kambing Marica di habitat aslinya masih sangat terbatas. Untuk itu perlu dilakukan suatu kajian mendasar tentang karakteristik morfologi dan perilaku makan sebagai dasar untuk dapat meningkatkan produktifitas, khususnya dalam hal peningkatan populasi untuk menghindari kemungkinan terjadinya kepunahan dari kambing Marica.

Hasil data awal yang telah dilakukan pada beberapa peternak mengindikasikan bahwa rendahnya populasi kambing Merica yang ada saat ini disebabkan oleh berbagai faktor. Faktor yang paling menonjol adalah kambing Marica pada umumnya dipelihara bersama kambing lain sehingga berpengaruh terhadap keberlanjutan hidup kambing marica itu sendiri sebab dikawinkan dengan kambing jenis lain. Disamping itu dimensi tubuh dari kambing Marica lebih kecil dibandingkan dengan kambing lainnya, hal ini menyebabkan kurangnya perhatian yang baik terhadap keberadaan kambing Marica bahkan cenderung untuk tidak mengembangkannya. Hal ini sejalan dengan penelitian yang dilakukan oleh Subandriyo dan Setiadi (2003) yang mengemukakan penyebab langkahnya kambing marica adalah semakin berkembangnya ilmu pengetahuan dan teknologi pemuliaan ternak, bioteknologi, permintaan pasar, mekanisme pertanian dan produksi ternak, akan mendorong eksploitasi ternak melalui persilangan, penggantian bangsa kambing baru. Hasil Penelitian Ngitung (2013) mengemukakan jumlah ternak Kambing Marica di Sulawesi Selatan hanya sekitar 0,007\% dari populasi kambing.

Fokus penelitian ini adalah untuk melihat bagaimana karakteristik morfologi dan perilaku makan pada kambing Marica ketika berada di luar habitat aslinya.

\section{Metode Penelitian}

\section{Jenis Penelitian}

Jenis penelitian ini adalah penelitian deskriptif yang bertujuan untuk mengumpulkan informasi mengenai status suatu gejala yang ada, yaitu keadaan gejala menurut apa adanya pada saat penelitian dilakukan. Penelitian ini dilakukan di Kebun Percobaan Biologi Universitas Negeri Makassar. Desain penelitian ini adalah penelitian deskriptif, dapat diartikan sebagai proses pemecahan masalah yang diselidiki dengan melukiskan keadaan subyek dan obyek penelitian pada saat sekarang berdasarkan fakta-fakta yang tampak atau apa adanya.

\section{Bahan Penelitian}

Sampel dalam penelitian ini menggunakan Kambing Marica Jantan (Capra sp) 1 ekor dan Kambing Marica Betina (Capra sp) 1 ekor yang ditempatkan di Kebun Percobaan Biologi Universitas Negeri Makassar.

\section{Prosedur Penelitian}

\section{Alat dan Bahan}

a. Alat

1) Alat yang digunakan untuk mengamati perilaku makan kambing Marica yaitu:

a) Stop Watch, untuk mengukur durasi atau lamanya aktivitas tingkah laku makan

b) Termometer dengan satuan celcius digunakan untuk mengukur suhu lingkungan

c) Timbangan $100 \mathrm{~kg}$ digunakan untuk menimbang ternak

d) Kamera digunakan untuk mendokumentasikan gambar selama penelitian

e) Daftar isian dan alat tulis-menulis.

2). Alat yang digunakan untuk menghitung dimensi tubuh kambing Marica yaitu:

a) Meteran $150 \mathrm{~cm}$ digunakan untuk mengukur atau menghitung dimensi tubuh

b) Kamera digunakan untuk mendokumentasikan gambar selama penelitian 


\section{b. Bahan}

c) Daftar isian dan alat tulis-menulis.

Adapun bahan yang digunakan dalam penelitian ini antara lain:

1) Kambing Marica Jantan (Capra sp) 1 ekor

2) Kambing Marica Betina (Capra sp) 1 ekor

3) Air

4) Pakan hijauan seperti Legum, rumput gaja mini dan rumput lapang.

\section{Prosedur Kerja}

\section{a. Pengukuran dimensi tubuh}

1) Tinggi pundak diukur mulai dari bawah kaki sampai punggung bagian depan dengan menggunakan meteran $150 \mathrm{~cm}$

2) Tinggi pinggul diukur mulai dari pangkal paha sampai punggung bagian belakang dengan menggunakan meteran $150 \mathrm{~cm}$. Panjaitan (2010), teknik pengukuran tinggi pinggul yang baik dapat dilakukan dengan langkah-langkah sebagai berikut : a) menempatkan ternak pada posisi/tempat yang rata dan pastikan ternak berdiri tegak secara alami; b) mengukur ternak dengan menempatkan mistar ukur tegak lurus dan pastikan bagian horizontal dari mistar persis berada di atas pinggul.

3) Panjang badan diukur mulai dari titik bahu sampai pangkal ekor dengan menggunakan meteran $150 \mathrm{~cm}$. Panjaitan (2010), Panjang badan adalah panjang dari titik bahu ke tulang duduk. Teknik pengukuran panjang badan yang baik dapat dilakukan dengan langkah-langkah sebagai berikut: a) siapkan alat berupa mistar ukur berbentuk lurus; b) tempatkan ternak pada posisi/tempat yang rata dan pastikan ternak berdiri tegak secara alami; c) ukur ternak dengan menempatkan mistar ukur pada bagian titik bahu sampai pada tulang duduk; d) catatan hasil pengukuran pada form isian yang telah disiapkan.

4) Lingkar dada diukur mulai dari titik awal lingkar dada secara melingkar dengan menggunakan meteran $150 \mathrm{~cm}$. Panjaitan (2010), teknik pengukuran lingkar dada yang baik dapat dilakukan dengan langkah-langkah sebagai berikut : a) menyiapkan meteran dengan panjang minimal $150 \mathrm{~cm}$; b) menyiapkan buku data untuk mencatat hasil pengukuran lingkar dada; c) memastikan ternak sudah tenang dan berdiri dengan posisi yang tegak; d) mencatat angka lingkar dada yang terukur pada meteran kedalam buku data.

5) Lebar dada diukur mulai dari sisi luar kanan dada sampai sisi luar kiri dada dengan menggunakan meteran $150 \mathrm{~cm}$.

6) Panjang telinga diukur mulai dari pangkal telinga sampai ujung telinga dengan menggunakan meteran $150 \mathrm{~cm}$

7) Lebar telinga diukur mulai dari sisi luar kanan telinga sampai sisi luar kiri telinga dengan menggunakan meteran $150 \mathrm{~cm}$

8) Bobot dadan dihitung dengan menggunakan timbangan $100 \mathrm{~kg}$

9) Panjang ekor diukur mulai dari pangkal ekor sampai ujung daging ekor dengan menggunakan meteran $150 \mathrm{~cm}$

10)Lebar ekor diukur mulai dari sisi luar kanan ekor sampai sisi luar kiri ekor

11)Panjang tanduk diukur mulai dari pangkal tanduk sampai ujung tanduk dengan menggunakan meteran $150 \mathrm{~cm}$.

\section{Pengamatan Perilaku Makan}

Pencatatan tingkah laku makan dilakukan dengan metode One Zero interval 15 menit. Tahapan tingkah laku diberi nilai satu bila dilakukan dan nol bila tidak dilakukan, dalam selang waktu 15 menit. Pengamatan tersebut dilakukan dalam dua kali ulangan untuk setiap individu 
berbeda. Tingkah laku yang diamati dibedakan dalam aktivitas makan, ruminansia dan istirahat. Aktivitas makan terdiri atas: 1) aktivitas mencium hijauan yaitu awal aktivitas mencium hingga kambing mulai melakukan aktivitas lainnya, 2) aktivitas merenggut makanan yaitu awal perenggutan hijauan hingga diangkat untuk dikunyah, 3) aktivitas mengunyah makanan yaitu aktivitas yang dimulai dari hasil perenggutan hijuauan yang telah dikumpulkan di dalam mulut, hingga melakukan aktivitas menelan ,4) aktivitas menelan makanan yaitu aktivitas yang dimulai dari menelan hasil kunyahan hingga aktivitas lainnya. Aktivitas ruminasi terdiri atas: 1) aktivitas mengeluarkan bolus yaitu aktivitas yang dimulai dari dikeluarkan bolus dari rumen menuju ke mulut hingga kambing melakukan aktivitas mengunyah bolus, 2) aktivitas mengunyah bolus, yaitu aktivitas yang dimulai dengan mengunyah bolus yang telah dikeluarkan dari rumen ke mulut hingga aktivitas menelan beberapa bolus, 3) aktivitas menelan bolus yaitu aktivitas yang dimulai dari bolus yang langsung ditelan setelah dikeluarkan dari rumen ke mulut atau menelan bolus yang melalui proses pengunyahan hingga aktivitas mengeluarkan bolus kembali.

\section{Analisis Data}

Hasil pencatatan tingkah laku, dihitung berdasarkan proporsi persentase yang terjadi selama interval tertentu dengan membagi jumlah tingkah laku yang teramati dalam interval dengan jumlah tingkah laku keseluruhan atau dengan rumus:

$$
\text { Tingkah Laku }=\frac{\mathrm{X}}{\mathrm{Y}} \times 100 \%
$$

Keterangan:

$\mathrm{X}=$ Pensentase suatu tingkah laku tertentu dalam 7 jam per individu (siang)

$\mathrm{Y}=$ Persentase keseluruhan tingkah laku yang diamati 7 jam per individu (siang).

\section{Hasil dan Pembahasan}

Tabel 1. Dimensi Tubuh Kambing Marica

\begin{tabular}{|l|c|c|}
\hline \multirow{2}{*}{\multicolumn{1}{c|}{ Dimensi Tubuh }} & Jantan & Betina \\
\cline { 2 - 3 } & 2 Pasang gigi permanen & 3 Pasang gigi permanen \\
\hline Bobot/kg & 19.26 & 16.34 \\
\hline Panjang badan/cm & 49.20 & 46.50 \\
\hline Tinggi pundak/cm & 46.20 & 44.92 \\
\hline Tinggi pinggul/cm & 51.80 & 40.50 \\
\hline Lingkar dada/cm & 43.60 & 45.25 \\
\hline Lebar ekor/cm & 4.80 & 4.18 \\
\hline Dalam dada/cm & 23.80 & 25.75 \\
\hline Panjang Tanduk/cm & 12.90 & 5.32 \\
\hline Panjang telinga/cm & 11.75 & 8.73 \\
\hline Lebar telinga/cm & 6.48 & 5.34 \\
\hline Type telinga & Tegak & Tegak \\
\hline Panjang ekor/cm & 13.10 & 10.78 \\
\hline Warna bulu & Coklat & Hitam \\
\hline
\end{tabular}


Tabel 2. Pola Tingkah Laku Makan Kambing Marica Betina (Capra sp) Terhadap Persentase Kambing Berdasarkan Alokasi Waktu

\begin{tabular}{|c|c|c|c|c|c|c|c|c|}
\hline \multirow[b]{2}{*}{$\begin{array}{c}\text { Jenis } \\
\text { Kelamin } \\
\end{array}$} & \multirow[b]{2}{*}{$\begin{array}{c}\text { Pola Tingkah Laku } \\
\text { Makan }\end{array}$} & \multicolumn{7}{|c|}{ Persentase Kambing Berdasarkan Alokasi Waktu (\%) } \\
\hline & & $\begin{array}{l}09.00- \\
10.00\end{array}$ & $\begin{array}{l}10.00- \\
11.00\end{array}$ & $\begin{array}{l}11.00- \\
12.00\end{array}$ & $\begin{array}{l}12.00- \\
13.00\end{array}$ & $\begin{array}{l}13.00- \\
14.00\end{array}$ & $\begin{array}{l}14.00- \\
15.00\end{array}$ & $\begin{array}{l}15.00 \\
16.00\end{array}$ \\
\hline \multirow{8}{*}{$\begin{array}{c}\text { Betina } \\
\text { (3 psg gigi) }\end{array}$} & Mencium & 9.81 & 13.62 & 12.8 & 11.58 & 10.57 & 7.2 & 20.58 \\
\hline & Merenggut & 12.21 & 16.7 & 13 & 16.01 & 19.44 & 10.64 & 22.9 \\
\hline & Mengunyah & 13.07 & 19.4 & 12.91 & 22.27 & 24.62 & 8.86 & 18.2 \\
\hline & Menelan & 11.85 & 10.62 & 8.18 & 11.42 & 14.43 & 6.97 & 7.33 \\
\hline & mengeluarkan bolus & 16.83 & 14.91 & 17.48 & 11.63 & 9.33 & 21.17 & 11.63 \\
\hline & mengunyah bolus & 16.2 & 12.29 & 17.42 & 13.33 & 9.12 & 18.97 & 9.99 \\
\hline & menelan bolus & 20.03 & 12.47 & 18.21 & 13.77 & 12.49 & 26.18 & 9.37 \\
\hline & TOTAL & 100 & 100 & 100 & 100 & 100 & 100 & 100 \\
\hline
\end{tabular}

Tabel 3. Pola Tingkah Laku Makan Kambing Marica Jantan (Capra sp) Terhadap Persentase Kambing Berdasarkan Alokasi Waktu

\begin{tabular}{|c|c|c|c|c|c|c|c|c|}
\hline \multirow[b]{2}{*}{$\begin{array}{c}\text { Jenis } \\
\text { Kelamin }\end{array}$} & \multirow[b]{2}{*}{$\begin{array}{c}\text { Pola Tingkah Laku } \\
\text { Makan }\end{array}$} & \multicolumn{7}{|c|}{ Persentase Kambing Berdasarkan Alokasi Waktu (\%) } \\
\hline & & $\begin{array}{l}09.00- \\
10.00\end{array}$ & $\begin{array}{l}10.00- \\
11.00\end{array}$ & $\begin{array}{l}11.00- \\
12.00\end{array}$ & $\begin{array}{l}12.00- \\
13.00\end{array}$ & $\begin{array}{l}13.00- \\
14.00\end{array}$ & $\begin{array}{l}14.00- \\
15.00\end{array}$ & $\begin{array}{l}15.00- \\
16.00\end{array}$ \\
\hline \multirow{8}{*}{$\begin{array}{c}\text { Jantan } \\
\text { (2 psg gigi) }\end{array}$} & Mencium & 13.76 & 8.21 & 18.52 & 9.9 & 8.74 & 17.93 & 15.97 \\
\hline & Merenggut & 18.42 & 12.92 & 22.28 & 11.3 & 14.56 & 22.74 & 23.17 \\
\hline & Mengunyah & 19.6 & 9.64 & 14.9 & 13.81 & 15.53 & 18.66 & 19.42 \\
\hline & Menelan & 11.88 & 11.79 & 11.84 & 9.21 & 9.75 & 11.59 & 10.65 \\
\hline & mengeluarkan bolus & 12.38 & 15.69 & 10.58 & 21.2 & 18.59 & 8.15 & 9.29 \\
\hline & mengunyah & 11.98 & 20.82 & 9.75 & 19.67 & 16.78 & 8.97 & 11.17 \\
\hline & menelan bolus & 11.98 & 20.92 & 12.12 & 14.92 & 16.23 & 11.96 & 10.33 \\
\hline & TOTAL & 100 & 100 & 100 & 100 & 100 & 100 & 100 \\
\hline
\end{tabular}

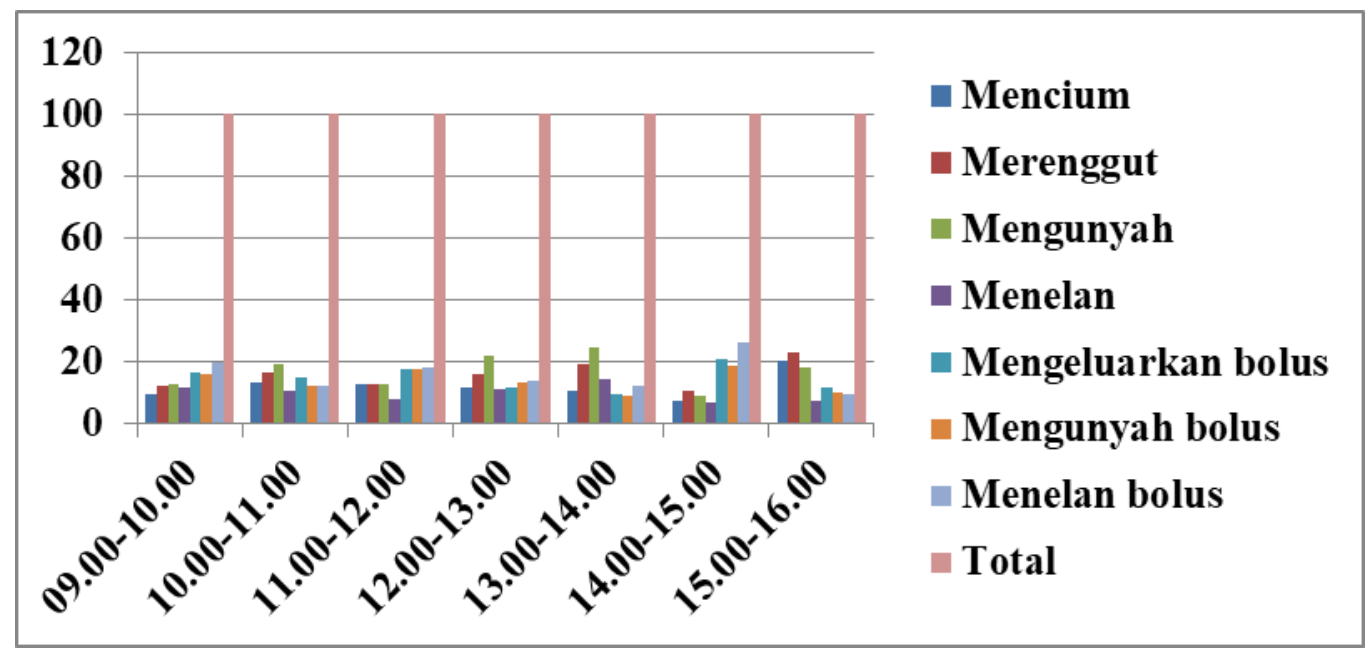

Gambar 1. Persentase Tingkah Laku Makan Kambing Marica Betina (Capra sp) Berdasarkan Alokasi Waktu 


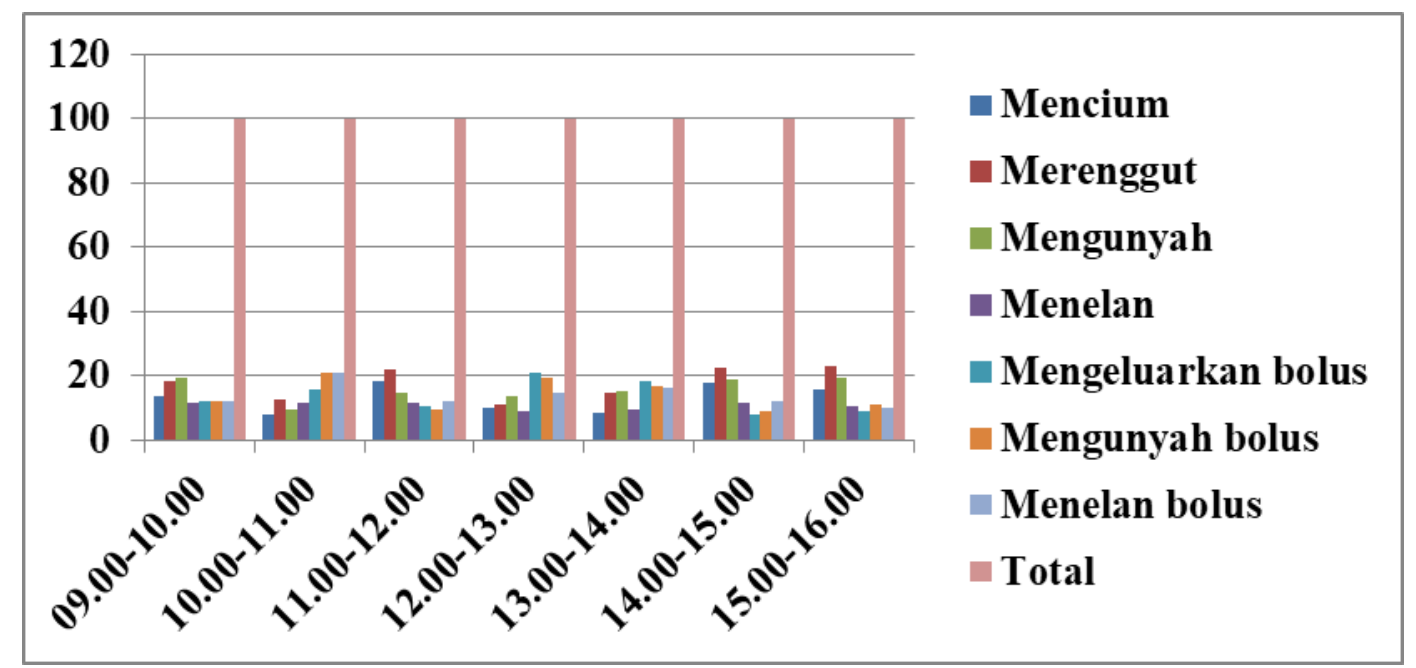

Gambar 2. Persentase Tingkah Laku Makan Kambing Marica Jantan (Capra sp) Berdasarkan Alokasi Waktu

\section{Pengamatan Dimensi Tubuh Kambing Marica}

Panjang badan kambing Marica jantan adalah 49,20 cm dan rataan panjang badan Kambing Marica betina adalah $46,50 \mathrm{~cm}$. Angka ini lebih rendah atau lebih kecil bila dibandingkan dengan penelitian sebelumya oleh Batubara (2007), yaitu 58,6 cm untuk jantan dan $66,4 \mathrm{~cm}$ untuk betina. Panjang badan merupakan jarak antara tepi depan sendi bahu dan tepi belakang tulang tapis. Cara pengukuran kita lakukan dengan menarik garis horizontal dari tepi depan sendi bahu sampai ke tepi belakang tulang tapis.

Tinggi pundak kambing Marica jantan adalah 46,20 cm dan rataan panjang badan Kambing Marica betina adalah 44,92 cm. Angka ini lebih rendah atau lebih kecil bila dibandingkan dengan penelitian sebelumya oleh Batubara (2007), yaitu 57,6 cm untuk jantan dan $65,7 \mathrm{~cm}$ untuk betina.

Bobot badan kambing Marica jantan adalah 19,26 kg dan rataan panjang badan Kambing Marica betina adalah 16,34 kg. Angka ini lebih rendah atau lebih kecil bila dibandingkan dengan penelitian sebelumya oleh Batubara (2007), yaitu 24,8 kg untuk jantan dan 26,2 kg untuk betina. Panjaitan (2010) mengemukakan bahwa Pengukuran berat badan ternak umumnya dilakukan untuk mengetahui perkembangan ternak sehingga dapat dimonitor dampak dari satu intervensi teknologi atau perbaikan manajemen. Berat badan dapat dijadikan salah satu indikator untuk mengetahui pertumbuhan dan perkembangan ternak Penimbangan hendaklah dilakukan dengan urutan dan tata cara yang tetap, agar mendapatkan berat badan yang mendekati kebenaran.

Tinggi pinggul Kambing Marica jantan adalah 51,80 cm dan rataan panjang badan Kambing Marica betina adalah 40,50 $\mathrm{cm}$. Angka ini lebih rendah atau lebih kecil bila dibandingkan dengan penelitian sebelumya oleh Batubara (2007), yaitu 59,7 cm untuk jantan dan 60,6 cm untuk betina.

Lingkar Kambing Marica jantan adalah $43.60 \mathrm{~cm}$ dan rataan panjang badan Kambing Marica betina adalah $45.25 \mathrm{~cm}$. Angka ini lebih rendah atau lebih kecil bila dibandingkan dengan penelitian sebelumya oleh Batubara (2007), yaitu 61,7 cm untuk jantan dan 64,4 cm untuk betina. Panjaitan (2010) mengemukakan lingkar dada (LD) merupakan salah satu dimensi tubuh yang dapat digunakan sebagai indicator mengukur pertumbuhan dan perkembangan ternak. pengukuran lingkar dada diukur pada tulang rusuk paling depan persis pada belakang kaki depan. Pengukuran lingkar dada dilakukan dengan melingkarkan pita ukur pada badan.

Lebar dada Kambing Marica jantan adalah 15,60 cm dan rataan panjang badan Kambing 
Marica betina adalah 15,57 $\mathrm{cm}$. Angka ini lebih rendah atau lebih kecil bila dibandingkan dengan penelitian sebelumya oleh Batubara (2007), yaitu 15,6 cm untuk jantan dan 15,9 cm untuk betina. Lebar dada adalah jarak antara sendi bahu kiri dan kanan.

Warna bulu bervariasi yaitu warna coklat dengan garis hitam dibagian Columna vertebrae untuk kambing Marica jantan dan warna hitam untuk kambing Marica betina.

Panjang tanduk Kambing Marica jantan adalah 12,90 cm dan rataan panjang badan Kambing Marica betina adalah 5,32 cm. Angka ini lebih rendah atau lebih kecil bila dibandingkan dengan penelitian sebelumya oleh Batubara (2007), yaitu 12,1 cm untuk jantan dan 7,4 cm untuk betina.

Bentuk telinga dan panjang telinga seekor hewan dalam hal ini kambing dapat pula dijadikan tanda dari suatu jenis bangsa, seperti halnya pada kambing Marica memiliki ciri khas dengan tipe telinga tegak dengan ukuran yang relatif kecil. Panjang telinga Kambing Marica jantan adalah 11,75 cm dan panjang badan Kambing Marica betina adalah 8,73 cm. Angka ini lebih rendah atau lebih kecil bila dibandingkan dengan penelitian sebelumya oleh Batubara (2007), yaitu 11,6 cm untuk jantan dan 10,3 cm untuk betina.

Lebar panjang ekor Marica jantan adalah 13,10 cm lebih tinggi atau lebih besar bila dibandingkan dengan penelitian sebelumnya oleh Batubara (2007) yaitu 11,3 cm. Panjang ekor Kambing Marica betina adalah 10,78 cm. Angka ini lebih rendah atau lebih kecil bila dibandingkan dengan penelitian sebelumya oleh Batubara (2007), yaitu 11,6 cm.

lebar ekor Kambing Marica jantan adalah 4,80 cm dan rataan panjang badan Kambing Marica betina adalah 4,18 cm. Angka ini lebih tinggi atau lebih besar bila dibandingkan dengan penelitian sebelumya oleh Batubara (2007), yaitu 3,6 cm untuk jantan dan 3,9 cm untuk betina.

\section{Perilaku Makan}

Pengamatan tingkah laku makan dimulai dari aktivitas makan dan ruminasi selama 7 jam pengamatan. Berdasarkan hail pengamatan pada gambar total aktivitas kambing marica paling tinggi terjadi pada pukul 09.00-10.00, kemudian dilanjutkan pada pukul 13.00-14.00. sedangkan untuk total aktivitas paling rendah terjadi pada pukul 11.00 sampai 12.00 yang dikuti dengan aktivitas makan dan aktivitas ruminitas yang rendah. Hal tersebut dapat disimpulkan bahwa aktivitas makan yang paling tinggi terjadi pada waktu pagi hari dan sore hari, hal ini disesuaikan dengan suhu dan keadaan lingkungan didaerah penelitian.

Tabel 1 menunjukan bahwa tingkah laku mencium paling rendah untuk kambing betina adalah pada pukul 09.00-10.00 (9.81\%) dan 14.00-15.00 (7.2\%). Hal tersebut diduga bahwa di pagi hari keadaan rumput hijauan masih banyak tersedia, sehingga kambing betina langsung memakan tanpa harus mencium terlebih dahulu.. Sedangkan untuk tingkah laku mencium kambing jentan paling rendah pada pukul 12.00-14.00 (18.78\%) dan 10.00-11.00 (8.21\%). Hal tersebut diduga karena kambing jantan lebih selektif memilih makan dipagi pagi hari terutama untuk jenis rumput yang disukai.

Rangkaian pola makan selanjutnya adalah merengut makanan yaitu aktivitas dimana kambing melakukan awal kali perenggutan pakan sampai diangkat untuk dikunyah. Adapun jenis makanan yang direngut seperi hijauan, semak belukar, ranting kulit tumbuh-tumbuhan. Kambing merenggut dengan cara menarik mulut kedepan atas atau belakang bawah. Menurut Devendra dan Burns (1994), kambing mempunyai kebiasaan makan yang berbeda dengan ruminansia lainnya. Bila tidak dikendalikan, kebiasaan makan dapat mengakibatkan kerusakan. Bibirnya yang tipis mudah digerakkan dengan lincah untuk mengambil pakan. Kambing mampu makan rumput yang pendek, dan merenggut dedaunan. Disamping itu, kambing merupakan pemakan yang lahap dari pakan yang berupa berbagai macam tanaman dan kulit pohon.

Dari Tabel 1 dan 2 di atas persentase renggutan paling tinggi untuk kambing betina terjadi pada pukul 13.00-14.00 (19.44\%) dan 15.00-16.00 (22.90\%) sedangkan untuk kambing jantan pada pukul 11.00-12.00 (18.52\%) dan 14.00-16.00 (45.91\%). Hal ini berarti pada waktu 
tersebut, makanan yang disukainya masih tersedia. Selain itu, setiap persentase kambing dalam merenggut hijauan dapat langsung dikunyah atau dengan persentase merenggut berkali-kali kemudian dikunyah. Setelah merenggut makanan ke dalam mulutnya, kambing akan memulai aktivitas berikutnya yaitu mengunyah. Fungsi pengunyahan selama makan yaitu untuk merusak bagian permukaan pakan sehingga ukuran pakan menjadi lebih kecil yang memudahkan pakan cepat dicerna. Frekeuensi pengunyahan yang paling banyak dilakukan kambing betina pada pukul 13.00-14.00 dan untuk kambing jantan pada pukul 14.00-16.00.

Jika aktivitas makan telah selesai, maka dilanjutkan dengan aktivitas ruminasi. Aktivitas ruminasi diawali dengan mengeluarkan bolus yang disimpan sementara dalam rumen untuk dikunyah dan ditelan kembali. Frekuensi aktivitas menelan bolus lebih banyak dilakukan dibanding aktivitas menelan makanan sebelum ruminasi, hal ini diduga karena pakan yang telah dikunyah kemudian di telan dan disimpan lama di dalam rumen. Menurut WodzickaTomaszewska et al. (1993), proses pengunyahan pada saat makan dan ruminasi merupakan aktivitas pelengkap di dalam pengurangan ukuran partikel. Partikel yang lebih kecil mungkin mempunyai waktu retensi yang relatif lebih pendek di dalam rumen, sehingga tingkat kecernaan tidak hanya ditentukan oleh tingkat kecernaan ingesta, tetapi juga oleh waktu tersimpan di dalam rumen.

Setelah kambing selesai melakukan aktivitas ruminitas biasanya dilanjutkan dengan tingkah laku istirahat. Tingkah laku ini merupakan tingkah laku dimana kambing sudah tidak melakukan apa-apa. Posisi istirahat yang dilakukan kambing terdiri dari tiga jenis yaitu, bersimpuh, berdiri dan berbaring dengan meletakan kepala di atas tanah dan mata terpenjam seperti tertidur.

Tingkah laku istirahat yang paling optimal dilakukan pada pukul 11.00 sampai 14.00 . Hal ini didukung suhu yang tinggi pada siang hari $29-34^{\circ} \mathrm{C}$, kambing akan lebih banyak melakukan istirahat. Kambing apabila dihadapkan pada cekaman panas, prioritas tingkah laku kambing akan berubah dari kegiatan merumput atau mengkonsumsi pakan untuk menghindari kondisi yang tidak menyenangkan. Konsekuensi yang cepat adalah mengurangi konsumsi pakan dan energi metabolis yang tersedia. Gangguan lain terhadap keseimbangan energi berasal dari perubahan fisiologi, endokrin dan pencernaan yang selanjutnya menurunkan energi yang tersedia. Hal ini sesuai dengan pernyataan Wodzicka- Tomaszewska et al. (1991) bahwa pada siang hari dengan suhu yang tinggi, kambing akan merumput lebih sedikit, waktu yang digunakan untuk ruminasi lebih singkat dengan istirahat yang relatif lama.

Wodzicka-Tomaszewska et al.,(1993) mengemukakan faktor lingkungan yang terpenting adalah suhu dan kelembaban, tetapi angin dan sinar matahari mempengaruhi kombinasi suhu dan kelembaban yang dibutuhkan untuk produksi yang optimum. Kambing yang dipelihara dengan cara digembalakan dan biasanya terkena sinar matahari langsung, dan tampaknya menderita karena cekaman panas. Kambing mempunyai bulu yang dapat memberikan perlindungan yang memadai terhadap pengaruh langsung sinar matahari, dan dapat memberikan manfaat untuk pengaturan panas oleh ternak yang terjemur sinar matahari. Sebagian energi dipantulkan sebagai pancaran gelombang pendek. Pemindahan panas secara paksa segera menyejukkan permukaan. Pengeluaran keringat ke permukaan tubuh oleh ternak yang menerima panas lingkungan dalam jumlah yang besar adalah cara yang tidak efisien untuk mengurangi beban panas tubuh, karena kambing sedikit berkeringat. Bulu memberikan perlindungan fisik dari pancaran sinar matahari langsung dan tak langsung serta pengaruh suhu udara efektif yang tinggi.

Dari semua aktivitas, aktivitas makan adalah paling tinggi. Hal ini disebabkan karena kambing termasuk hewan diurnal, yaitu aktivitas makan di siang hari dan malam hari digunakan untuk istirahat. Selain itu hijauan tersedia bisa memenuhi kebutuhan hidupnya. Meskipun hijauan yang kurang disukainya banyak tersedia di kandang dan habitatnya, tetapi jika tumbuh tanaman muda, maka kambing akan memakannya. Hal ini karena tanaman muda yang sedang tumbuh mempunyai kandungan protein yang relatif tinggi. Jantan lebih tinggi 
persentasi makannya di banding betina, hal ini diduga karena faktor umur berpengaruh besar dalam aktivitas makan. Umumnya jantan remaja lebih aktif dalam mengambil hijauan, meskipun harus lebih selektif dalam mengambil hijauan tapi jantan remaja lebih mudah dalam mengambil hijauan yang disukainya.

Morand-Fehr (1981) mengemukakan aktivitas yang paling rendah selama waktu pengamatan adalah aktivitas ruminansia. Hal ini diduga karena aktivitas ruminansia umumnya dilakukan pada malam hari, namun aktivitas tersebut dipengaruhi juga oleh pola merumput. Aktivitas istirahat antara jantan dan betina tidak berbeda nyata. Hal ini diduga aktivitas istirahat selalu bersamaan antara jantan dan betina. Setiap ada satu jantan yang berjalan menuju kandang, maka kambing lainnya mengikuti ke arah yang sama, meskipun ada kambing yang masih melakukan aktivitas makan. Hal ini menunjukkan bahwa pada kambing yang ada di lokasi penelitian memiliki sifat berkelompok. Sifat tersebut didukung adanya tipe adaptasi fisiologi yaitu kebiasaan, artinya adaptasi yang melibatkan pengurangan respon terhadap rangsangan berulang dan biasanya terkait dengan penurunan persepsi setelah rangsangan yang berulang. Perubahan tingkah laku terjadi pada tingkat sensoris.

\section{Kesimpulan}

Kesimpulan dari penelitian ini adalah karakteristik tubuh kambing marica dengan kambing lainya berbeda baik dari segi bobot, panjang badan, lebar badan, panjang tanduk, panjang ekor, lebar telinga, lebar dada dan sebagainya. Ciri yang paling khas pada kambing ini adalah telinga tegak, relatif kecil dan pendek, tanduk pendek kecil serta lincah dan agresif dan perilaku makan kambing Marica, pada siang hari (09.00-16.00) lebih banyak melakukan aktivitas makan. Dalam pengamatan, kambing makan lebih aktif di pagi hari dan sore hari (09.00-10.00 dan 13.00-16.00). Aktivitas makan, ruminansia dan istirahat selama waktu pengamatan antara jantan dan betina tidak berbeda nyata. Aktivitas merenggut tanaman adalah yang paling banyak dilakukan dibanding dengan kegiatan lainnya.

\section{Referensi}

Batubara. A, (2007). Tujuh Plasma Nutfah Kambing Lokal Indonesia. Sinar Tani, Jakarta edisi 25 April - 1 Mei 2007.

Devendra,C.. \& Burns. M, (1994). Produksi kambing di Daerah Tropis, Denpasar. Penerbit ITB dan Universitas Udayana.

Ngitung R. (2013). Studi Biologis Kambing Marica sebagai Plasma Nutfah endemic di Sulawesi Selatan . Disertasi Doktor. Universitas Hasanuddin.

Panjaitan, tanda. (2010). Pengukuran Ternak. Kementerian Pertanian Badan Penelitian dan Pengembangan Pertanian. Balai Pengkajian Teknologi Pertanian. NTB.

Riswandi \& Muslima, G. A. (2018). Manajemen Pemberian Pakan Ternak Kambing di Desa Sukamulya Kecamatan Indralaya Utara Kabupaten Ogan Ilir. Jurnal Peternakan Sriwijaya, 7 (2).

Subandriyo \& Setiadi B. (2003). Pengelolaan plasma nutfah hewani sebagai aset dalam pemenuhan kebutuhan manusia. Makalah disampaikan dalam Lokakarya Pemantapan Pengelolaan Database dan Pengenalan Jejaring Kerja Plasma Nutfah Pertanian, Bogor, 21- 28 Juli 2003, Komisi Nasional Plasma Nutfah. 
Wodzicka-Tomaszewska, M. (1991). Reproduction in relation to animal production in Indonesia. Indonesian.

Wodzicka-Tomaszewska, M. (1993). Small ruminant production in the humid tropics.

\begin{tabular}{|l|l|}
\hline Rosdiana Ngitung & $\begin{array}{l}\text { Ir., M.P., Dr. Dosen Jurusan Biologi, Fakultas Matematika dan Ilmu } \\
\text { Pengetahuan Alam, Universitas Negeri Makassar. } \\
\text { E-mail:rosdiana.ngitung@yahoo.com }\end{array}$ \\
\hline Mushawwir Taiyeb & $\begin{array}{l}\text { M.Kes., Dr. Dosen Jurusan Biologi, Fakultas Matematika dan Ilmu } \\
\text { Pengetahuan Alam, Universitas Negeri Makassar. } \\
\text { E-mail: } \underline{\text { mtaiyeb333@gmail.com }}\end{array}$ \\
\hline Irma Suryani Idris & $\begin{array}{l}\text { S.p.KK, M.Kes., dr. Dosen Jurusan Biologi, Fakultas Matematika dan } \\
\text { Ilmu Pengetahuan Alam, Universitas Negeri Makassar. } \\
\text { E-mail: irmaaries@yahoo.com }\end{array}$ \\
\hline
\end{tabular}

